\title{
Allozyme variation in the butterfly, Maniola jurtina (Lepidoptera: Satyrinae) (L.): evidence for selection
}

\author{
D. GOULSON \\ NERC Institute of Virology and Environmental Microbiology, Mansfield Road, Oxford, OX1 3SR, U.K.
}

\begin{abstract}
This paper describes patterns of allozyme variation in the butterfly, Maniola jurtina (L.). Twelve loci, of which four were polymorphic (PGM, PGI, IDH-1 and IDH-2), were screened across 14 populations in south-east England. The patterns described are not in agreement with expectation for a sedentary butterfly in which alleles are neutral to selection, for geographically distant populations differed very little in gene frequencies. Geographic homogeneity is compatible with either a higher degree of vagility than expected for this species or similar selection pressures maintaining allele frequencies across the area sampled. Associations between patterns of variation at two loci and behavioural, morphological and environmental variables suggested that selection may be acting upon them. In particular, the genotype at the locus for $P G M$ affected the length of time for which individual butterflies could fly continuously, while $P G M$ allozyme frequencies varied according to the altitude of the site. The frequency of allozymes at $I D H-2$ was correlated with the mean size of individuals in both sexes when comparing sites. Possible causes of these associations are discussed. I conclude that patterns of variation in the loci studied are probably not good estimators of population structuring, but are more likely to be the result of selection.
\end{abstract}

Keywords: altitude, morphology, mutase, phosphoglucose, polymorphism, selection, temperature.

\section{Introduction}

The meadow brown butterfly, $M$. jurtina (Lepidoptera: Satyrinae) (L.), the subject of numerous papers spanning 30 years by E. B. Ford, W. H. Dowdeswell and others (summarized in Dowdeswell, 1981), and more recently by P. Brakefield (Brakefield, 1984; Brakefield \& Noordwijk, 1985), provides one of the cornerstones of early research in population genetics. Most of this work has concentrated on the genetics and spatial and temporal variation of black spotting on the hind wing. The species is ubiquitous and abundant in grassland and scrub habitats throughout the western palearctic, and is considered to be relatively sedentary (Pollard, 1981).

This study describes patterns of allozyme variation in M. jurtina within and among sample sites in southeast England, and attempts to evaluate whether the observed patterns are best explained by neutrality or selection at the loci concerned. The use of both allozyme and morphological variation enables information inferred from one source to be cross-checked against the other. To quote Singh \& Long (1992) 'The use of both molecules and morphology allows us to understand the causes of geographic variation in more detail than by studying either of them in isolation. Yet it is remarkable how few (such) species .... have been done during the past 25 years'. Despite the lack of any clear consensus as to the relative importance of selection and stochastic processes in controlling allozyme frequencies (Mani, 1984), electrophoretic data are often used to infer information on population structure (e.g. Grant \& Little, 1992; Bilton, 1992) with the implicit assumption that selection pressures on the loci used are weak or absent.

An assessment of population structure in $M$. jurtina using allozyme variation is compared with that expected for a sedentary species. I also examine evidence for selection influencing allozyme frequencies by testing for associations with butterfly morphology, physiology and altitude at which they were sampled. These variables were chosen on the basis of associations with electrophoretic data in other studies of Lepidoptera (see discussion). 


\section{Materials and methods}

Five hundred and sixty-five adult butterflies were hand-netted at 14 sites in south-east England (Fig. 1) during the flight season in 1990. Sample sizes are given in Table 1. The sampling sites were divided geographically into two clusters, one in Oxfordshire containing 10 sites, and the other in East Sussex containing four sites. This sampling design enabled detection of local geographic variation $(<1 \mathrm{~km})$ and larger scale patterns between sites sufficiently distant from each other to prevent any likelihood of direct dispersal in a sedentary species (maximum distance between sites $165 \mathrm{~km}$ ) (it should be noted that there were undoubtedly unsampled populations between these distant sites). Within each cluster, sites were chosen to represent each of the main habitat types of $M$. jurtina, namely lowland meadow (sites 1, 3, 4, 7 and 8) woodland clearings (sites 2, 5 and 6) and chalk grassland (sites 9 to 14 ).
Butterfly abdomens were removed and stored at $-70^{\circ} \mathrm{C}$ until electrophoresis could be carried out. The remainder of the butterfly was retained for morphological analysis. Individual numbering of specimens and electrophoretic material enabled associations between genotype and morphology to be examined. Abdomens were individually homogenized in numbered centrifuge tubes with $0.3 \mathrm{ml}$ of extraction buffer (Pasteur et al., 1988).

Proteins were separated using horizontal starch gel electrophoresis following the method described by Pasteur et al. (1988). A variety of gel and electrode buffer systems were used and 16 enzymes screened. The two most suitable buffer systems proved to be continuous Tris-citrate at $p \mathrm{H} 8$ (Ahmad et al., 1977) and discontinuous citrate histidine at $p \mathrm{H} 7$ (Shaw \& Prasad, 1970). Gels were run at $60 \mathrm{~mA}$ for $4.5 \mathrm{~h}$.

Enzyme staining protocols are given in Pasteur et al. (1988). Twelve enzymes were clearly resolved, of which four proved to be polymorphic: phosphoglucose

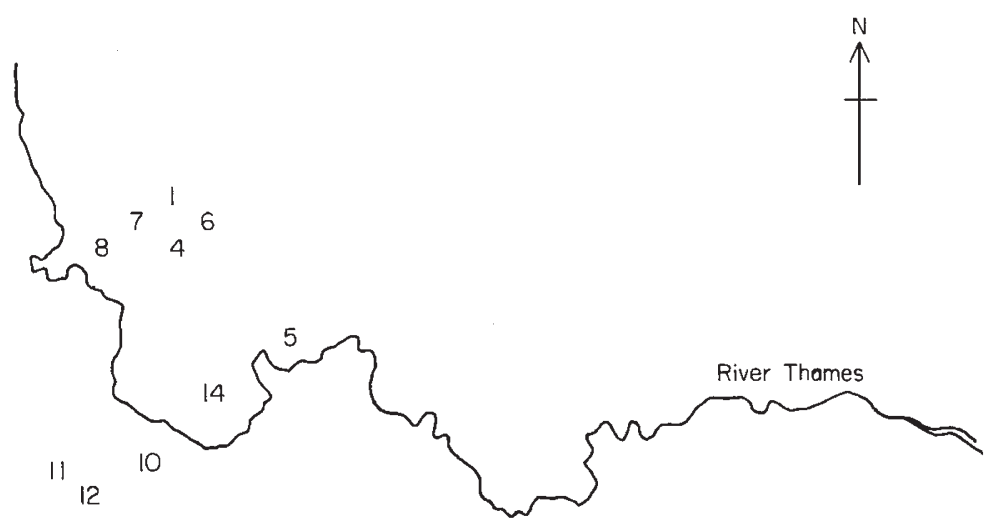

9

Fig. 1 Study sites in south-east England.

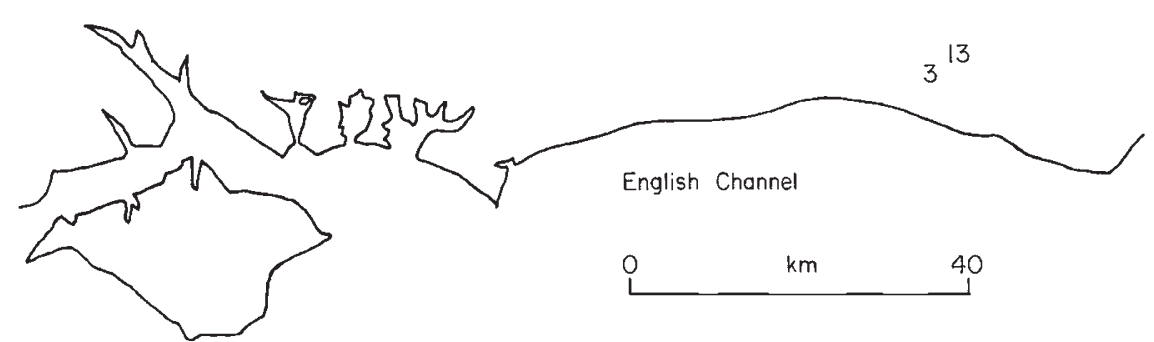


Table 1 Sample allele frequencies for the four polymorphic loci studied ${ }^{*}=$ missing values. Only the two most common alleles are shown

\begin{tabular}{|c|c|c|c|c|c|c|c|c|c|c|}
\hline \multirow[b]{2}{*}{ Site No. } & \multirow[b]{2}{*}{ Site N.G.R. } & \multicolumn{2}{|l|}{$P G I$} & \multicolumn{2}{|l|}{$P G M$} & \multicolumn{2}{|l|}{$I D H-I$} & \multicolumn{2}{|l|}{$I D H-2$} & \multirow[b]{2}{*}{$(N)$} \\
\hline & & $P G I^{100}$ & $P G I^{150}$ & $P G M^{100}$ & $P G M^{85}$ & $I D H-1^{100}$ & $I D H-1^{65}$ & $I D H-2^{100}$ & $I D H-2^{68}$ & \\
\hline 1 & SP607112 & 0.823 & 0.069 & 0.795 & 0.151 & 0.895 & 0.105 & 0.956 & 0.044 & 144 \\
\hline 2 & TQ582275 & 0.793 & 0.069 & 0.733 & 0.200 & $*$ & * & 0.897 & 0.103 & 29 \\
\hline 3 & TQ450086 & 0.857 & 0.071 & 0.841 & 0.114 & 0.864 & 0.136 & 1.000 & 1.000 & 21 \\
\hline 4 & SP601096 & 0.865 & 0.014 & 0.829 & 0.092 & 0.838 & 0.149 & 0.986 & 0.014 & 37 \\
\hline 5 & SP724958 & 0.837 & 0.083 & 0.738 & 0.086 & 0.878 & 0.130 & 0.969 & 0.033 & 58 \\
\hline 6 & SP612104 & 0.800 & 0.067 & 0.897 & 0.129 & 0.870 & 0.167 & 0.967 & 0.018 & 30 \\
\hline 7 & SP589095 & 0.883 & 0.091 & 0.806 & 0.148 & 0.833 & 0.000 & 0.964 & 0.000 & 30 \\
\hline 8 & SP540060 & 0.864 & 0.071 & 0.759 & 0.096 & 1.000 & 0.019 & 0.955 & 0.019 & 22 \\
\hline 9 & TQ565305 & 0.839 & 0.121 & 0.750 & 0.034 & 0.981 & 0.125 & 0.944 & 0.018 & 28 \\
\hline 10 & SU546862 & 0.759 & 0.051 & 0.914 & 0.069 & 0.875 & 0.082 & 0.982 & 0.069 & 29 \\
\hline 11 & SU530850 & 0.867 & 0.043 & 0.853 & 0.214 & 0.918 & 0.196 & 0.922 & 0.000 & 49 \\
\hline 12 & SU535850 & 0.783 & 0.057 & 0.738 & 0.129 & 0.804 & 0.000 & 1.000 & 0.029 & 23 \\
\hline 13 & TQ445088 & 0.900 & 0.117 & 0.800 & 0.150 & * & $*$ & 0.971 & 0.000 & 35 \\
\hline 14 & SP675915 & 0.783 & 0.077 & 0.717 & 0.194 & 0.942 & 0.125 & 1.000 & 0.022 & 30 \\
\hline
\end{tabular}

mutase $(P G M)$, phosphoglucose isomerase $(P G I)$, isocitrate dehydrogenase $1(I D H-l)$ and isocitrate dehydrogenase $2(I D H-2)$.

Malate dehydrogenase, glucose-6-phosphate dehydrogenase, adenylate kinase, aldolase and glyceraldehyde phosphate dehydrogenase were resolved and found to be monomorphic in all samples analysed.

\section{Other variables screened}

Flying ability. To test whether flying ability varied according to genotype at the four loci under study, 34 male butterflies from site 1 were captured and stored in the dark. They were then removed individually, placed in a brightly lit flight cage $1 \mathrm{~m}^{3}$ at $29^{\circ} \mathrm{C}$ and stimulated into flight with a gentle tap. As soon as they settled they were stimulated again. Eventually this failed to provoke further flight. The total time from initial stimulation to this point was recorded.

Morphology. The sex, the length of the forewing from base to apex and the number of hindwing spots were recorded for all butterflies sampled.

Altitide. The altitude of study sites was obtained from Ordnance Survey maps.

\section{Statistical analyses}

Agreement with Hardy-Weinberg proportions was tested using both $F$-statistics and a $\chi^{2}$ test for goodness of fit with Levene's (1949) correction for small samples. As the $\chi^{2}$ test is likely to be unreliable when expected values are low (Sokal \& Rohlf, 1981), the $\chi^{2}$ test was repeated with the genotypes pooled into the three classes (i) homozygotes for the most common allele; (ii) heterozygotes for the most common allele; and (iii) other genotypes. Departures from Hardy-Weinberg were only considered significant if both $\chi^{2}$ tests were significant.

Statistical significance was adjusted throughout to account for the increase in type I errors expected when carrying out multiple tests, using Cooper's (1968) modification where the critical probability for rejection of the null hypothesis is $\alpha / n$, and where $n$ is the number of loci tested.

Heterozygosities were calculated from the expected number of heterozygotes in each sample assuming Hardy-Weinberg equilibrium.

$F_{i s}$, (inbreeding in the individual relative to the sample), $F_{s t}$ (the standardized variance of allele frequencies among samples), and $F_{i t}$ (inbreeding in the individual relative to the whole population), were calculated for 15 alleles at the four polymorphic loci (Nei, 1977; Wright, 1978). Null hypothesis $\left(F_{i s}=0\right.$, $F_{i t}=0$ and $F_{s t}=0$ ) were tested using:

$\chi^{2}=N F_{i s}^{2} ; \quad$ d.f. $=1$

$t=\left|F_{I T} \sqrt{N}\right| ; \quad$ d.f. $=$ infinity

$\chi^{2}=2 N F_{s t} \quad$ d.f. $=$ number of sites -1 ,

where $N=$ total number of individuals $(565)$.

The island model of migration was used to estimate the number of individuals dispersing between sites $(m)$ 
according to $F_{s t}=1 /(1+4 m)$ (adapted from Wright, 1951).

Genetic distances between samples were calculated using Nei's (1978) unbiased distance (Wright, 1978, provides an excellent discussion of these and other measures). Wright's modification of Rogers' (1972) distance, and Nei's (1972) distance were also calculated and gave similar results.

\section{Results}

Gel banding patterns were in accordance with the dimeric nature of enzymes $P G I$ and $I D H$, in which heterozygotes exhibited clear hybrid bands equidistant between the bands for each allele. PGM is a monomer and displayed no hybrid bands in heterozygotes. Average heterozygosities for all polymorphic loci ranged from 0.148 to 0.280 , with a mean of 0.218 .

The frequency of the most common allozymes of $P G M, P G I, I D H-I$, and $I D H-2$ at each site, and sample sizes are shown in Table 1. Interpretation of the data as allelic frequencies is further supported by a $\chi^{2}$ goodness of fit test for deviation from Hardy-Weinberg expectations (combining classes where expected values were less than five). Of the 56 sample/locus combinations only one departed significantly from expectation. In sample 6 at the locus for $P G I$ there was a lack of heterozygotes (unpooled $\chi^{2}=28.49$, d.f. $=10$, $P=0.002, F=0.223$ ).

$F$ statistics for 14 alleles (Table 2) describe a high degree of geographic uniformity and suggest random mating between individuals both within and between samples. Values of $F_{\text {is }}$ vary from -0.061 to 0.035

Table $2 F$-statistics for the 14 most common alleles (values of $F_{i s}$ and $F_{i t}$ are mean values for all 14 sites sampled)

\begin{tabular}{|c|c|c|c|c|c|}
\hline Allele & $\begin{array}{l}\text { Average } \\
\text { frequency }\end{array}$ & $\begin{array}{l}\text { Sample } \\
\text { variance }\end{array}$ & $F_{s t}$ & $F_{i s}$ & $F_{i t}$ \\
\hline$P G M^{100}$ & 0.794 & 0.002 & 0.017 & -0.004 & 0.013 \\
\hline$P G M^{75}$ & 0.018 & 0.000 & .011 & -0.026 & -0.015 \\
\hline$P G M^{85}$ & 0.132 & 0.002 & 0.019 & -0.011 & 0.008 \\
\hline$P G M^{110}$ & 0.028 & 0.000 & 0.005 & -0.033 & -0.028 \\
\hline$P G M^{1,30}$ & 0.027 & 0.000 & 0.005 & 0.024 & 0.029 \\
\hline$P G I^{100}$ & 0.833 & 0.002 & 0.009 & -0.013 & -0.004 \\
\hline$P G I^{10}$ & 0.023 & .000 & 0.019 & -0.041 & -0.021 \\
\hline$P G I^{30}$ & 0.046 & 0.001 & 0.010 & -0.061 & -0.051 \\
\hline$P G I^{70}$ & 0.008 & 0.000 & 0.005 & -0.015 & -0.010 \\
\hline$P G I^{130}$ & 0.015 & 0.000 & 0.015 & -0.030 & -0.015 \\
\hline$P G I^{150}$ & 0.072 & 0.001 & 0.008 & 0.014 & 0.022 \\
\hline$I D H-1^{100}$ & 0.904 & 0.001 & 0.021 & 0.031 & 0.051 \\
\hline$I D H-1^{65}$ & 0.095 & 0.001 & 0.020 & 0.035 & 0.054 \\
\hline$I D H-2^{100}$ & 0.965 & 0,000 & 0.018 & -0.057 & -0.039 \\
\hline$I D H-2^{68}$ & 0.026 & 0.000 & 0.021 & -0.054 & -0.032 \\
\hline
\end{tabular}

(mean -0.005$)$, values of $F_{i t}$ vary from -0.051 to 0.054 (mean -0.010 ), and values of $F_{s t}$ vary from 0.005 to 0.021 (mean 0.015). All are non-significant. These generally low values of $F_{s t}$ result in high estimates of dispersal between sites using the island model of migration. Estimates for individual alleles vary from 11.7 to 49.8 individuals immigrating into each sample site per generation, with a mean of 16.4 .

The significance of allele frequency differences between sites was also tested using a $\chi^{2}$ contingency test for heterogeneity (combining frequencies where expected values were low). $I D H-2$ was the only locus at which allozyme frequencies differed significantly between sites $(P<0.0001)$.

Nei's genetic distance $(D)$ varied from 0 to 0.013 for the possible 91 between-site comparisons. There was no apparent association between geographic distance and genetic heterogeneity (linear regression, $r^{2}=0.022$, ns): some sites separated by $165 \mathrm{~km}$, such as 3 and 4 , where genetically identical $(D<0.0005)$. Conversely other site pairs separated by only $1 \mathrm{~km}$ were towards the upper range of values of $D$ found (for example, sites 10 and $11, D=0.008$ ).

There was no increase in genetic similarity between samples taken from similar habitats, for genetic distances were not significantly smaller when comparing within habitats than between (mean values of $D$, between habitats, 0.003; within meadows, 0.002; woodlands, 0.006; chalk grasslands, 0.004).

\section{Evidence for selection upon allozyme frequencies}

Evidence for selection upon allozyme frequencies suggested by associations between allozymes and other variables is summarized in Table 3 .

Isocitrate dehydrogenase 2. Allozyme frequencies of $I D H-2$ are correlated with size when comparing sites. The frequency of allozyme $I D H-2^{100}$ is negatively correlated with mean wing length in both sexes, (Pearson product-moment correlation coefficient $r=-0.481, \quad P<0.005$ in males, $r=-0.648$, $P<0.001$ in females).

Phosphoglucose mutase. I. In between-site comparisons the frequency of the most common allozyme $\left(P G M^{100}\right)$ declines with increasing altitude (linear regression, $\left.P=0.014, r^{2}=0.406\right)$. This relationship is not linear (Fig. 2). At low altitudes sites occur with a wide range of frequency of $P G M^{100}$, while at higher altitudes (above $120 \mathrm{~m}$ ) all sites have a comparatively low frequency.

This result appears to contradict the finding that $P G M$ allozyme frequencies do not differ between sites. 
Table 3 Summary of relationships between allele frequencies and morphological and environmental variables

\begin{tabular}{|c|c|c|c|}
\hline Enzyme & $\begin{array}{l}\text { Associated } \\
\text { variable }\end{array}$ & Description of relationship & $\begin{array}{l}\text { Statistical test and } \\
\text { significance level }\end{array}$ \\
\hline \multirow[t]{2}{*}{$P G M$} & Altitude & $\begin{array}{l}\text { Frequency of } P G M^{100} \text { declines with } \\
\text { altitude }\end{array}$ & $\begin{array}{l}\text { Linear regression, } \\
r^{2}=0.406 \\
P=0.014\end{array}$ \\
\hline & Stamina & $\begin{array}{l}\text { At } 29^{\circ} \mathrm{C} \text { the stamina of individuals } \\
\text { homozygous for } P G M^{100} \text { is greater than } \\
\text { that of other genotypes (combined) }\end{array}$ & $t$-test, $P=0.002$ \\
\hline$I D H-2$ & Wing length & $\begin{array}{l}\text { Comparing site means the frequency of } \\
I D H-2^{100} \text { is negatively correlated with } \\
\text { mean wing length }\end{array}$ & $\begin{array}{l}\text { Correlation, } \\
r=-0.481, \\
P<0.005 \text { for } \\
\text { males, } r=-0.648, \\
P<0.001 \text { for } \\
\text { females }\end{array}$ \\
\hline
\end{tabular}

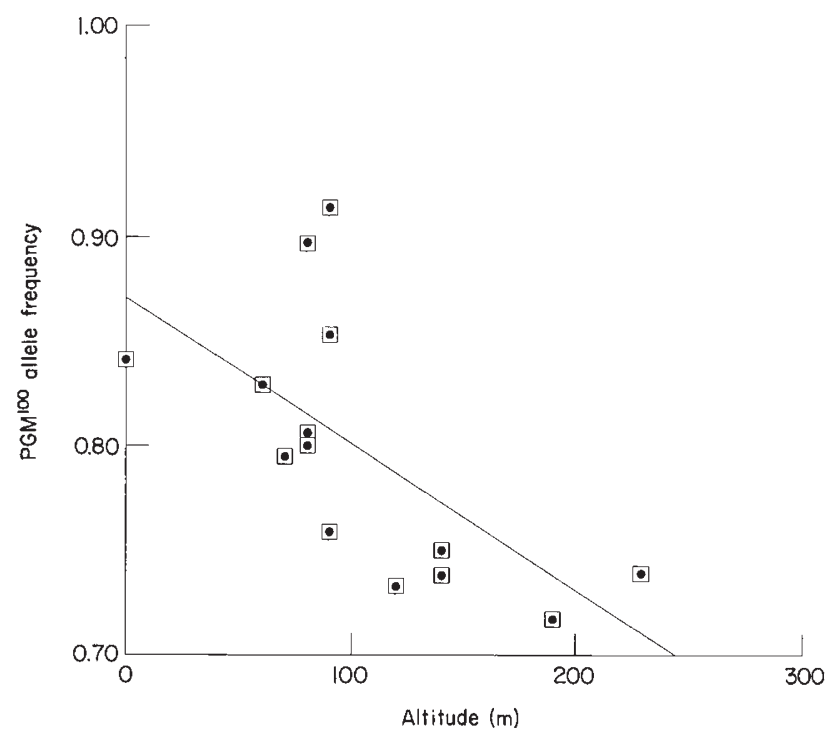

Fig. 2 Changes in $P G M^{100}$ allele frequency with altitude of the sample site.

From Table 1 it can be seen that frequencies of $P G M^{100}$ are similar at all sites, varying from 0.717 at site 14 to 0.914 at site 10 . Although these differences are not significant, when ordinated according to altitude the relationship is significant.

II. The ability to sustain continuous flight at $29^{\circ} \mathrm{C}$ is significantly higher in individuals homozygous for $P G M^{100}$ ( $t$-test, $\left.P=0.002\right)$. The mean length of flight for individuals homozygous for $P G M^{100}$ is $10.47 \mathrm{~s}$ $(n=17)$, and for other genotypes combined is $2.21 \mathrm{~s}$ (six individuals of genotype $P G M^{100}-P G M^{85}$, and one of $P G M^{100}-P G M^{75}$ ).
Isocitrate dehydrogenase $I$ and phosphoglucose isomerase. These loci were not significantly correlated with any morphological, behavioural or site variable measured.

Sex and hindwing spot number are not associated with genotype at any of the loci studied.

\section{Discussion}

If dispersal is low, and allele frequencies neutral to selection, then founder effects and genetic drift should result in genetic divergence between sample sites which is proportional to the degree of isolation (Sokal \& Wartenberg, 1983). Even allowing for the undoubted existence of stepping stone populations between the more distant populations in this study, the remarkable genetic uniformity between and within all samples is not consistent with expectations for a sedentary species. Estimates of dispersal between samples based on the mean value of $F_{s t}$ suggest that sample sites are subject to a constant influx of immigrants. Comparison with mean $F_{s t}$ values from other studies on Lepidoptera and a small selection of other organisms (Table 4) suggests that $M$. jurtina is highly vagile; its value of $F_{s t}$ $(0.015)$ is close to that for the known migrant, Pieris rapae $\left(F_{s t}=0.014\right)$, and is far lower than that of known sedentary species such as Euphydryas editha $\left(F_{s t}=0.118\right)$.

This estimate assumes that patterns of allele frequency are not subject to selection: if they are, then estimates of population structuring will be wrong. Selection may maintain similar gene frequencies in isolated populations provided that the selection pressures are the same at all sites. 
Table 4 Summary of $F_{s t}$ values from studies on Lepidoptera and a small selection of other organisms $\left(^{*}\right)$

\begin{tabular}{|c|c|c|c|c|}
\hline Name & $F_{s t}$ & No. of loci & Sampling area & Reference \\
\hline Spodoptera exempta & 0.006 & 6 & $\begin{array}{l}\text { Kenya, Tanzania, } \\
\text { Zimbabwe }\end{array}$ & Den Boer (1978) \\
\hline Alabama argillacea & 0.007 & 13 & Mexico, Brazil & Pashley (1985) \\
\hline Danaus plexippus & 0.009 & 6 & Eastern U.S.A. & $\begin{array}{l}\text { Eanes \& Koehn } \\
(1978)\end{array}$ \\
\hline Papilio glaucus & 0.013 & 13 & New York State & $\begin{array}{l}\text { Hagen \& Lederhouse } \\
(1985)\end{array}$ \\
\hline Pieris rapae & 0.014 & 4 & U.S.A. & Eanes \& Koehn (1978) \\
\hline M. jurtina & 0.015 & 4 & S.E. England & Present study \\
\hline Anticarsia gemmatalis & 0.021 & 19 & Eastern U.S.A., Mexico & Pashley (1985) \\
\hline Danaus plexippus & 0.032 & 6 & Australia & $\begin{array}{l}\text { Hughes \& Zalucki } \\
(1984)\end{array}$ \\
\hline Drosophila melanogaster* & 0.044 & 7 & Eastern U.S.A. & Eanes \& Koehn (1978) \\
\hline Heliothios virescens & 0.048 & 10 & $\begin{array}{l}\text { Southeast and Western } \\
\text { U.S.A., Mexico }\end{array}$ & Sluss \& Graham (1979) \\
\hline Cydia pomonella & 0.066 & 4 & $\begin{array}{l}\text { Africa, Europe, U.S.A., } \\
\text { Australia }\end{array}$ & Pashley $(1980)$ \\
\hline Spodoptera frugiperda & 0.084 & 13 & $\begin{array}{l}\text { Caribbean, Mexico, } \\
\text { Eastern U.S.A. }\end{array}$ & Pashley et al.(1985) \\
\hline Euphydryas chalcedona & 0.090 & 8 & Central California & McKechnie et al. (1975) \\
\hline Euphydryas editha & 0.118 & 8 & Central California & McKechnie et al. $(1975)$ \\
\hline Homo sapiens* & 0.148 & 9 & Worldwide & Cavalli-Svorza (1966) \\
\hline $\begin{array}{l}\text { Hydroporus glabriusculus } \\
\text { (Coleoptera)* }\end{array}$ & 0.199 & 9 & Britain, Sweden & Bilton (1992) \\
\hline $\begin{array}{l}\text { Rumina decollata } \\
\text { (Mollusca)* }\end{array}$ & 0.294 & 5 & Approx. $5,400 \mathrm{~m}^{2}$ & $\begin{array}{l}\text { Selander \& Hudson } \\
\text { Hudson }(1976)\end{array}$ \\
\hline
\end{tabular}

Two of the four loci studied are significantly associated with other variables measured. Such associations may be attributed to 'hitchhiking' via close linkage to other loci (Thomson, 1977), but linkage disequilibrium between a neutral and selected locus is transitory (Clegg, et al., 1980; Asmussen \& Clegg, 1981; 1982). Thus although a possible cause of associations within a single population, hitchhiking is not a plausible explanation for patterns of geographic variation in gene frequency.

Previous studies on butterflies have rarely combined electrophoresis with morphological or behavioural studies, but those that have concluded that selection acts upon allozyme frequencies (McKechnie et al., 1975; Watt, 1977; Eanes \& Koehn, 1978; Hughes \& Zaluki, 1984; Watt et al., 1986).

\section{Variation in isocitrate dehydrogenase 2}

There are several possible causes of the observed relationship between size and genotype. It may be due to a direct effect of genotype at IDH-2 upon size, for example via larval growth rate. Alternatively it may be a non-causative effect of linkage to other genes involved in growth. Given the relationship between female size and fecundity reported in numerous studies of Lepidoptera, for example Lederhouse (1981) and Jones et al. (1982), the relationship between $I D H-2$ and size is likely to result in powerful selection pressures on this loci.

\section{Variation in phosphoglucose mutase}

The frequency of $P G M^{100}$ declined with altitude of the site. Examination of data published by Masetti \& Scali $(1976,1978)$ reveals a similar trend in five populations of $M$. jurtina from Italy, for two mountain populations possessed lower frequencies of the most common allele than populations sampled near sea level. Similarly, data presented by Bullini et al. (1975) describe a decline in frequency of the most common allele with decreasing latitude in samples from Switzerland and Italy. However, it is unknown whether the most common allele is the same in each case.

Variation in the ability of butterflies to maintain flight at $29^{\circ} \mathrm{C}$ provides a possible explanation for this observation, for individuals homozygous for $P G M^{100}$ could maintain flight for far longer than individuals of other genotypes tested. Why then do alleles other than $P G M^{100}$ persist at this locus? Presumably at some time 
during the life cycle, or at temperatures other than $29^{\circ} \mathrm{C}$ selection is reversed. The increase in frequency of rare alleles in samples taken at higher altitudes suggests temperature may be the variable which balances selection. During cool conditions heterozygotes may be more able to fly than individuals homozygous for $P G M^{100}$. Clearly further research is needed to establish whether this is so.

Associations between altitude, weather and flight activity have been recorded with regard to PGI allozyme frequencies in Colias sp. (Watt, 1983; Watt et al., 1983, 1985), and PGM and PGI frequencies in Danaus plexippus (Carter et al., 1989). Hovanitz (1948) found that the different wing colour morphs of Colias sp. are active at different air temperatures, so that samples of active individuals from the same site varied in morph frequency according to the weather. If the fitness of different morphs varies according to the weather then short-term temporal heterogeneity of weather conditions could maintain polymorphisms, with fluctuations in morph frequencies from year to year depending upon the weather conditions during the flight period.

In conclusion, the low $F_{s t}$ obtained for M. jurtina is probably not indicative of a high dispersal rate, but is more likely the result of selection acting upon at least some of the polymorphic loci studied.

\section{Acknowledgements}

I would like to thank Drs Denis Owen, Andrew Lack, Tim Shreeve, Alen Grafen, Tristram Wyatt and Robert L. Hammond for discussion and advice while carrying out this work.

\section{References}

AHMAD, M. SKIBINSKI, D. O. F. AND BEARDMORE, J. A. 1977. An estimate of the amount of genetic variation in the common mussel Mytilus edulis. Biochem. Genet., 15, 833-846.

ASMUSSEN, M. A. AND CleGG, M. T. 1981. Dynamics of the linkage disequilibrium function under models of genefrequency hitchhiking. Genetics, 99, 337-356.

ASMUSSEN, M. A. AND CLEGG, M. T. 1982. Rates of decay of linkage disequilibrium under two-locus models of selection. $J$. Math. Biol., 14, 37-70.

BILTON, D. T. 1992. Genetic population structure of the Postglacial relict diving beetle Hydroporus glabriusculus Aube (Coleoptera: Dytiscidae). Heredity, 69, 503-511.

BRAKEFIELD, P. M. 1984. The ecological genetics of quantitative character in Maniola jurtina and other butterflies. In: Vane-Wright, R. I. and Ackery, P. R. (eds) The Biology of Butterflies, Symposium of the Royal Entomological Society, Academic Press, London, pp. 167-190.

BRAKEFIELD, P. M. AND NOORDWIJK, A. J. VAN. 1985. The genetics of spot pattern characters in the meadow brown Maniola jurtina (Lepidoptera: Satyridae). Heredity, 54, 275-284.
BULlini, L., CIANCHI, R., NASCETTI, G. AND RENNA, L. 1975. Phosphoglucomutase polymorphism in seven Lepidoptera species. Rend Accademy Nazionale Lincei, 59, 814-821.

CARTER, P. A., HUGHES, J. M. AND ZALUKI, M. P. 1989. Genetic variation in a continuously breeding population of Danaus plexippus L.: an examination of heterozygosity at four loci in relation to activity times. Heredity, 63, 191-194.

CAVAlli-SFORZA, L. L. 1966. Population structure in human evolution. Proc. Roy. Soc. (B), 196, 362-379.

CLEGG, M. T., KIDWELL, J. F. AND HORCH, C. R. 1980. Dynamics of correlated genetic systems V. Rates of decay of linkage disequilibria in experimental populations of Drosophila melanogaster. Genetics, 94, 217-234.

COOPER, D. W. 1968. The significance level in multiple tests made simultaneously. Heredity, 23, 614-617.

DEN BOER, M. H. 1978. Isoenzymes and migration in the African armyworm, Spodoptera exempta (Lepidoptera, Noctuidae). J. Zoology, 185, 539-553.

DOWDESWELL, W. H. 1981. The Life of the Meadow Brown. Heinemann Educational Bks Ltd., London.

EANES, W. F. AND KOEHN, R. K. 1978. An analysis of genetic structure in the monarch butterfly Danaus plexippus (L.). Evolution, 32, 784-797.

GRANT, w. S. AND LITTLE, R. M. 1992. How sedentary are greywing francolins (Francolinus africanus)? Evolution. 46, 1477-1491.

HaGeN, R. H. AND Lederhouse, R. C. 1985. Polymodal emergence of the tiger swallowtail Papilio glaucus (LepidopteraL Papilionidae): source of a false second generation in central New York state. Ecol. Entomol., 10, 19-28.

HOVANitz, w. 1948. Differences in the field activity of two female color phases of Colias butterflies at various times of the day. Contributions from the Laboratory of Vertebrate Biology, 41, 1-37.

HUGHES, J. M. AND ZALUKI, M. P. 1984. Genetic variation in a continuously breeding population of Danaus plexippus L. (Lepidoptera: Nymphalidae). Heredity, 52, 1-7.

JONES, R. E., HART, J. R. AND BULL, G. D. 1982. Temperature, size and egg production in the cabbage butterfly Pieris rapae. Aust. J. Zool., 30, 223-232.

LEDERHouse, R. C. 1981. The effect of female mating frequency on egg fertility in the black swallowtail Papilio polyxenes asterius (Pap.). J. Lepid. Soc., 35, 266-277.

LEVENE, H. 1949. On a matching problem arising in genetics. Ann. Math. Stat., 20, 91-94.

MAN1, G. S. 1984. Genetic diversity and ecological stability. In: Shorrocks, B. (ed.) Evolutionary Ecology, 23rd Symposium of the British Ecological Society, Blackwell Scientific Publications, Oxford, pp. 363-396.

MASETTI, M. AND SCALI, v. 1976. Electrophoretic studies on gene-enzyme systems in Maniola jurtina: the PGM polymorphism in central Italy. Atti Accademy nazionale Lincei $R c, 8$ (58), 822-830.

MASETTI, M. AND SCALl, v. 1978. Distribuzione degli allozimi PGM nell'areale del lepidopttero Maniola jurtina (L.). Atti Association genetic Italia, 23, 177-179.

McKeCHNIE, S. W., EHRLICH, P. R. AND WHITE, R. B. 1975. Population genetics of Euphydryas butterflies I. Genetic variation and the neutrality hypothesis. Genetics, 81, 571-594. 
NEI, M. 1972. Genetic distance between populations. Am. Nat., 106, 283-292.

NEI, M. 1977. F-statistics and analysis of gene diversity in subdivided populations. Ann. Human Genet., 41, 225-233.

NEI, M. 1978. Estimation of average heterozygosity and genetic distance from a small number of individuals. Genetics, 89, 583-590.

PASHLEY, D. 1980. Genetic comparisons between native and introduced populations of the codling moth, Laspeyresia pomonella (Tortricidae) and other Tortricid species. Ph.D Thesis, University of Texas, Austin.

PASHLEY, D. P. 1985. Use of population genetics in migration studies: a comparison of three noctuid species. In: Barfield, C., Berger, R. D., Kennedy, G. G. and MacKenzie, D. R. (eds) Movement and dispersal of biotic agents, Louisiana State University, Baton Rouge.

PASHLEY, D. P., JOHNSON, S. J. AND SPARKS, A. N. 1985. Genetic population structure of migratory moths: and fall armyworm (Lepidoptera: Noctuidae). Ann. Ent. Soc. Am., 78, 757-761.

PASTEUR, N., PASTEUR, G., BONHOMME, F., CATALAN, J. AND BRITTONDAVIdIAN, J. 1988. Practical Isozyme Genetics. EllisHorwood Ltd., London.

POLLARD, E. 1981. Aspects of the ecology of the meadow brown butterfly, Maniola jurtina (Lepidoptera: satyridae). Ent. Gaz., 32, 67-74.

ROGERS, J. S. 1972. Measures of genetic similarity and genetic distance. Studies in genetics, University of Texas Publications, 7213, 145-153.

SELANDER, R. K. AND HUDSON, R. O. 1976. Animal population structure under close inbreeding: the land snail Rumina in southern France. Am. Nat., 110,695-718.

SHAW, C. R. AND PRASAD, R. 1970. Starch gel electrophoresis of enzymes- a compilation of recipes. Biochem. Genet., 4, 297-320.
SINGH, R. S., AND LONG, A. D. 1992. Geographic variation in Drosophila: from molecules to morphology and back. Trends in Ecology and Evolution, 7, 340-345.

SLUSS, T. P. AND GRAHAM, H. M. 1979. Allozyme variation in natural populations of Heliothis virescens. Ann. Ent. Soc. Am., 72, 317-322.

SOKAL, R. R. AND ROHLF, F. J. 1981. Biometry. Freeman, San Fransisco.

SOKAL, R. R. AND WARTENBERG, D. E. 1983. A test of spatial autocorrelation analysis using an isolation by distance model. Genetics, 105, 219-237.

THOMSON, G. 1977. The effect of a selected locus on linked neutral loci. Genetics, 85, 753-788.

WATT, w. B. 1977. Adaptation at specific loci I. Natural selection on phosphoglucose isomerase of Colias butterflies: biochemical and population aspects. Genetics, 87, 177-194.

WATT, w. B. 1983. Adaptation at specific loci II. Demographic and biochemical elements in the maintenance of the Colias GPI polymorphism. Genetics, 103, 691-724.

WATT, W. B., CASSIN, R. C. AND SWAN, M. S. 1983. Adaptation at specific loci III. Field behaviour and survivorship differences among Colias PGI genotypes are predictable from in vitro biochemistry. Genetics, $\mathbf{1 0 3}, 725-739$.

WATT, W. B., CARTER, P. A. AND BLOWER, S. M. 1985. Adaptation at specific loci IV. Differential mating succes among glycolytic allozyme genotypes of Colias butterflies. Genetics, 109, 157-175.

WATT, W. B., CARTER, P. A. AND DONAHUE, K. 1986. Female choice of 'good genotypes' as mates is promoted by an insect mating system. Science, 233, 1187-1190.

WRIGHT, s. 1951. The genetical structure of populations. Annals of Eugenics, 15, 323-354.

WRIGHT, S. 1978. Evolution and the genetics of populations, vol. 4. Variability within and among natural populations. University of Chicago Press, Chicago. 